\title{
Abstract
}

\section{A Comparison of Residence Hall Experience for Students of Different Backgrounds}

\begin{abstract}
The current study explored the impact of students' residence hall experience in terms of academic, social and personal development and students' motivation to join residence hall activities at a Hong Kong university. The results revealed significant differences, with females, local and non-first-year student groups reporting more gains from their residential hall experience relative to male, non-local and first-year students. Findings are useful in the refinement of the residence hall system to cater for students of diverse backgrounds.
\end{abstract}

\section{Introduction}

University experience is valuable in that it gives students the opportunity to step out of their comfort zone, whether it is through academic pursuit or participation in out-of-class activities. While academic endeavor is certainly an important component of this experience, the latter is also a significant contributor to a student's life-long development and growth. One major component of out-of-class activities is the experience of living in a residence hall (Franklin, 2013). The significance of residence hall living is supported by a number of developmental theorists. The student involvement theory (1984) postulated by Astin suggested that the physical and psychological energy invested in the academic experience is related to the desirable outcomes of a higher education institution. Of the various forms of student involvement in university, one important facet is peer group involvement, whereby greater involvement is associated with better student learning and personal development (Astin, 1993). Since hall residence tends to encourage interaction between students through various forms of hall activities, residential hall life can profoundly affect students in terms of academic, social and personal development. Academic development relates to one's perception and motivation for academic achievement, social development is associated with interpersonal communication and interaction with others, and personal development refers to the development of oneself. Students' development is heavily influenced by their experience in residence halls through the enhancement of the learning experience and achievement of the university's education aims (Hall Education Development Project, 2012). Additionally, hall education includes a variety of activities contributing to the well-rounded development of students, such as hall orientations, sports and cultural activities, high table dinners, and mentorship schemes. Living in halls can not only provide opportunities for social, cultural and extracurricular involvement, this involvement also has the potential to improve students' learning experience (Flowers, 2004; Holdsworth, 2006). Therefore, hall education is an important area of investigation, especially for educators.

A number of empirical studies pointed out that residence hall life can shape the learning experience of students and improve undergraduate education (Flowers, 2004; Holdsworth, 2006; Yang \& Chau, 2011). When compared to students who live at home and commute to school, those living in residence halls have been found to participate in more extra-curricular, social and cultural activities (Arboleda, Wang, Shelley, \& Whalen, 2003; Curley, 2003), interact more frequently with faculty and peers (Bray, 2006; Pike, Schroeder, \& Berry, 1997), be more likely to aspire to a graduate degree (Astin, 1984; Long, 2014), have better personal development in terms of their autonomy and selfconcept (Flowers, 2004) and be more committed to the university (Bray, 2006; Engstrom \& Tinto, 2009).

Aside from the general benefits of living in residence halls, it is essential to understand how students from diverse backgrounds are affected differently by resident hall experience. The social identity theory suggested that society is perceived as containing multiple groups, such as gender and nationality (Hornsey, 2008; Trepte \& Loy, 2017). Based on these perceived groups, people tend to identify themselves with certain groups, thereby impacting their behaviors and self-concept. Following this line of thought, it becomes logical to conclude that the residential hall experience can be vastly different as students come from a range of backgrounds. Since their self-perception will likely differ 
according to their identifications with their social groups, and the activities they engage in, the rationale behind and their general hall experience can be dissimilar. The present research can thus add value by taking students' background into account when understanding their hall experience.

Gender difference is one aspect considered by previous studies. One study showed that not only were male students more involved in hall activities than females, they also achieved better academic results (Arboleda et al., 2003). In contrast, Roland and Enochs (2006) reported that females relied on socialization and relationship formation experiences more than males, and they were better able to utilize their hall experience in forming social relationships, resulting in better social development. In a related vein, Kuh and $\mathrm{Hu}$ (2002) suggested that males were likely to be either extremely engaged or disengaged in campus activities, whereas females' engagement was more consistent. As the existing findings have not yielded consistent results, how hall experience affects male and female students remains inconclusive.

Another variable that has been studied is nationality. In the present research, participants were categorized into non-local and local students. The former refers to students who require a student visa or entry permit to Hong Kong for education purposes, while the latter refers to those who do not need such documents to study in Hong Kong (The University of Hong Kong, n.d.). Past studies found that non-local students face more psychological and emotional difficulties compared to local students, such as experiencing difficulties in making friends and adapting to local culture (Kashima \& Loh, 2006; Zepke \& Leach, 2005). It has been theorized that each campus holds a common habitus, which refers to the norms and practices shared by students of similar backgrounds, aspirations and attitudes (Berger, 2000; Thomas, 2002). This often applies to the dominant student - that is, the local students in this case. Indeed, some studies revealed that locals tend to be more involved in hall activities than non-locals (Arboleda et al., 2003; Beekhoven, 2002; Farris, 2010). Another study investigating individuals who were more involved in residence halls observed that the majority group students showed greater involvement than the minoritized group students (Arboleda et al., 2003; Volet \& Ang, 2012). This was presumed to be associated with the majority group students' higher comfort level with respect to the hall residence environment. Likewise, due to the relatively less involvement within minoritized students, it was postulated that they might turn to other experiences, such as concentrating on academic study. According to the demographics of this university, the proportion of local-students far exceeds non-local students in residence halls. Thus, previous findings can be viewed as a reference in exploring hall involvement among students of different nationalities.

Alongside gender and nationality factors, students' year of study is another key factor that researchers have examined (Huhn, 2006; Roland \& Enochs, 2006; Yang \& Chau, 2011). The first year of university is believed to be particularly crucial since the likelihood of making gains in learning is greatest for most students (Tinto \& Goodsell, 1993; Yorke \& Longden, 2008). According to Tinto (1986), first-year students go through a process of separation, transition and incorporation. The residence hall will thus play an influential role in providing an environment that enables newcomers to find an early physical, social and academic anchor during the transition to university, facilitating their integration into the broader campus social system in the long term (Newbrough, 1992; Tinto, 1993). Nevertheless, while there are a number of existing studies on first-year students' hall experience, there has been relatively little research on the hall experience of non-first-year students. One of the few studies reported that senior students tended to be less involved in hall activities, presumably because they focused on other areas, such as academic study (Arboleda et al., 2003). Research examining the impact of non-first-years' involvement in clubs and organizations offers further evidence suggesting that students of different level of study are affected differently while engaging in the same activity. For example, Foubert and Grainger (2006) found that first-years tended to experience greater personal development than non-first-years. Consequently, comparing the hall experience of students from different level of study may yield interesting findings.

The investigation of residential hall experience seldom included student's motivations as a variable. It seems that while a majority of studies explored students' outcomes as a result of living in a residence hall (e.g., Li, Sheely, \& Whalen, 2005; López Turley \& Wodtke, 2010), the rare research that examined students' motivations tended to place its focus on other aspects of university education, such as quality of academic and career advising (e.g., Sherry, Bhat, Beaver, \& Ling, 2004; Wawrzynski \& Jessup-Anger, 2010). Understanding students' motivations for joining hall activities is imperative as it offers a glimpse of their expectations of hall life. The variable can also predict students' satisfaction of their hall experience as they compare the reality of living in hall to their initial 
motivations in joining hall activities. Indeed, a study on students' social expectations reported that those whose expectations were fulfilled tended to be more socially integrated in university (Helland, Stallings, \& Braxton, 2002). Besides, students' motivations can profoundly affect their hall experience, such as influencing the extent of their involvement in hall activities. Consequently, in light of the limited study on student's motivation, the article aims to bridge such research gaps by examining students' motivations to join or not to join hall activities.

As mentioned, student gender, nationality and year of study are three major individual differences that can significantly affect students' hall experience, yet, most studies merely investigated one or two of these factors only. While some research explored males' and females' hall experience (e.g., Long, 2014; McCluskey-Titus \& Oliver, 2001), others examined the experience in relations to student's level of study (e.g., Farris, 2010; Huhn, 2006). Meanwhile, some studies were more concerned with the the impact of students' nationality and other factors, such as gender and level of study on hall experience (e.g., Arboleda et al., 2003; Dusselier, Dunn, Wang, Shelly, \& Whalden, 2005; López Turley \& Wodtke, 2010). This creates a niche to examine how students from different backgrounds are affected by their hall experience.

Currently, most studies on hall education were predominantly conducted in Western countries with the generalizability of those findings remaining questionable due to differences in geographical and cultural settings. This is especially evident in Hong Kong universities as there have been limited studies concerning students' involvement in out-of-class activities, let alone research on hall education (Tam, 2002; Yang \& Chau, 2011). Though theories such as the student involvement theory (1984) can be useful in understanding student's involvement in hall education, it was seldom examined in the Asian context. While Ting, Chan, and Lee (2016) found a positive correlation between multiple desirable variables and living in a residence hall, it is only the first step in understanding the nature of residence halls with regard to Hong Kong students. Differences between the West and the East can suggest different experience for hall education, especially when considering the contrast between western individualism and eastern collectivism. Given that the present research is conducted at a Hong Kong university with a strong Western philosophical background in emphasizing "whole-person education," the interplay between the two cultures may yield interesting findings pertaining to hall education in Hong Kong (Ting et al., 2016). For this reason, it is critical to gather more information on the impact of hall education. Research in the Asian context would thus be helpful in gaining a thorough understanding of the matter.

Based on the rationale that individual differences are central to different hall experiences, it was hypothesized that hall education would affect students from diverse backgrounds differently. It was also predicted that males and females, local and non-local, and first-year and non-first-year students would have different reasons for joining hall activities.

\section{Method}

\section{Design and Procedure}

The study used a between-participant independent t-test design to compare the impact of hall education and reasons for joining hall activities across students from diverse backgrounds. An independent t-test compares the mean difference between two treatment conditions or between two different populations (Gravetter \& Wallnau, 2009, p. 308). In this case, the independent variables were student gender (males and females), nationality (local and non-local) and year of study (firstyear and non-first-year). The dependent variable was the different impact of hall experience, which was divided into academic, social, and personal development. Another dependent variable was reasons for joining hall activities. Undergraduate students at a public university in Hong Kong were recruited by convenience sampling to participate in the study via high table dinners. Students invited were residing in one of the 13 residence halls within The University of Hong Kong. All students were given opportunities to complete the questionnaires in hard copies or online, which took approximately 15 minutes. This study was carried out in accordance with the recommendations of The University of Hong Kong and the protocol was approved by the Faculty Research Ethics Committee. All participants gave written informed consent in accordance with the university policy. 
Materials

A questionnaire was used for this study, which consisted of three sections: demographic information, the impact of hall experience and reasons for joining hall activities. Questions within the demographic information section comprised 4 items in total, including student gender, student status, faculty (a division within a university that the student belong), and year of study (an indication of the particular stage the student is in within a programme of study). The section on the impact of hall experience was divided into three parts, with a total of 33 items. The first part concerned academic development and consisted of 4 items. This was followed by social development, which included 12 items. The last part was personal development, which contained 17 items. Ratings for all three parts were evaluated on a 5 point Likert scale ranging from $1=$ Strongly Disagree to $5=$ Strongly Agree, an option of Don't Know was also included. The third section of the questionnaire asked participants to rate their reasons for joining hall activities, with a scale consisting of 12 items, which were evaluated on a 5 point Likert scale ranging from $1=$ Not a reason for me to $5=$ Very important reason for me.

\section{Participants}

The student sample consisted of 1,234 undergraduate students, including 558 males and 652 females (see Table 1). Regarding students' nationality, 811 were local, and 378 were non-local students. As for student's year of study, 480 were first-year students, while 740 were non-first-year students. Students came from a range of faculties, such as Business and economics (24\%), Engineering (15\%), Medicine (13\%) and Science (14\%).

\section{Results}

There was no significant difference in academic development between gender and between first-year and non-first-year students (see Table 2). However, the results revealed that non-local students reported a stronger drive to achieve academic/professional excellence than local students, $t(1232)=$ $2.17, p<0.05$, whereas local students reported more enthusiasm for learning than non-local students, $t(1232)=2.17, p<0.05$.

Again, there were no significant differences in terms of social development between first-year and non-first-year students (see Table 3). In terms of gender difference, females reported more gains in most of the measures on social development compared to males. Similarly, the nationality comparison indicated that local students also reported more gains in social development when compared to their non-local counterparts, common measures included being more aware of the thoughts and feelings of other people, $p<0.05$, being more able to see things from other people's point of view $p<0.05$, improving skills in social communication $p<0.05$, collaborating with other people in completing tasks $p<0.05$ and negotiating with others in coming to a decision $p<0.05$. However, when compared to local students, it is noteworthy that non-local students reported more gains in being aware of their roles as responsible global citizens $p<0.05$ and seeing things from a global perspective $p<0.05$.

Regarding personal development, there were no significant differences in all measures between firstyear and non-first-year students except in leadership gains (see Table 4). Non-first-years reported having acquired more leadership skills, $t(1232)=2.17, p<0.05$ and feeling more confident in taking up a leadership role than first-years, $t(1232)=2.17, p<0.05$.

In terms of gender comparison, females reported more gains in most of the measures on personal development compared to males. Similarly, local students also reported more gains in this aspect when compared to their non-local counterparts. These common measures included being more able to look at things from different perspectives, further developing skills that enable engagement in lifelong learning, feeling more confident about tackling unfamiliar problems, and learning more about how to identify a problem and tackle it (all $p<0.05)$. 
The comparison of reasons for joining hall activities between males and females showed nonsignificant differences across all items except for increasing the chance of re-admission, where females $(M=3.24, S D=1.16)$ rated it as a greater motivation than males $(M=3.16, S D=1.24 ; p$ $<0.05)$ (see Table 5).

Significant differences were found when comparing local and non-locals' incentives for joining hall activities. Non-local students rated commitment/contribution to hall and increasing the chance of readmission higher than did local students $(p<.05)$. On the other hand, local students rated peer encouragement $(M=3.34, S D=0.91)$ and peer pressure $(M=2.60, S D=0.99)$ higher than did nonlocal students $(\mathrm{M}=3.17, \mathrm{SD}=1.11 ; p<0.05)$.

For first-year and non-first-year students, reasons for joining hall activities differed significantly. Firstyears rated all reasons higher than non-first-years, except for peer pressure, which found no significant result. Examples of significant findings included personal interest as a greater motivation for first-years $(M=4.15, S D=0.79)$ than for non-first-years $(M=4.10 ; S D=0.80 ; p<0.05)$. The desire to experience a well-rounded university life also revealed a similar pattern, with first-years $(M=$ $4.04, \mathrm{SD}=0.82)$ rating it higher than non-first-years $(\mathrm{M}=3.87, \mathrm{SD}=0.86 ; p<0.05)$.

\section{Discussion}

As stated in the literature review, a residence hall is not only a place for accommodation, it is also crucial in affecting students' university experience (Franklin, 2013). The present study sought to examine how students with diverse backgrounds could be affected differently by their hall experience. Additionally, reasons for joining hall activities were also compared across different students. As predicted, students of different genders, nationalities and year of study were affected to different extents in their academic, social and personal development. The results also indicated that university students of different backgrounds had different reasons for joining hall activities.

Pertaining to the impact of hall experience for males and females, no significant gender differences were found in terms of academic development as residence hall living was equally beneficial to both genders in this aspect. This is contrary to previous research that reported a gender difference in academic outcomes (Arboleda et al., 2003; Long, 2014; Roland \& Enochs, 2006). However, significant gender differences were found in social and personal development, with females experiencing more gains in communication and intrapersonal skills. Examples were gaining confidence in tackling unfamiliar problems and looking at things from different perspectives. The results are consistent with past research reporting that females were better at forming relationships in residence halls, which in turn fostered their social development (Roland \& Enochs, 2006). Hence, it seems that residence hall living is more beneficial to females in cultivating social skills such as perspective taking and social communication.

In terms of reasons for joining hall activities, there was no gender difference apart from females were significantly more motivated by re-admission to hall than males. This suggests that females were more encouraged to join hall activities due to extrinsic factors than by personal interest.

Some differences were found in terms of the impact of hall experience on students of different nationalities. While non-local students reported greater academic development, local students seemed to benefit more in social and personal development, which is consistent with past research that revealed better academic performance among non-local students (Arboleda et al., 2003; Volet \& Ang, 2012). However, non-local students' high ratings for academic development were in stark contrast to their significantly lower ratings for social and personal development. This is congruent with past studies reporting the challenge of making friends for non-local students (Kashima \& Loh, 2006; Zepke \& Leach, 2005). Indeed, their lack of social development suggests a pursuit of alternative opportunities instead, such as spending more time on academic matters (Arboleda et al., 2003; Volet \& Ang, 2012). Consequently, more research is needed to ensure that local and non-local students benefit from hall experience equally.

The present study revealed that non-local students tended to participate in hall activities because of their desire to commit/contribute to the hall and to secure accommodation, whereas local students 
were more significantly influenced by peers when deciding whether or not to participate in hall activities. Thus, it seems that non-local students wished to be more active members of the hall. Past literature offers further insights in suggesting that the lack of belonging among non-locals can explain their desire for togetherness through participating in hall activities (Arboleda et al., 2003;

Beekhoven, 2002; Zepke \& Leach, 2005). At the same time, their decision to join hall activities might be motivated by their practical need for accommodation. This is in contrast to local students, who are socially influenced to participate in hall activities. The present study substantiates this view as it was found that peer encouragement and peer pressure were the major reasons for local students to engage in hall activities. This is consistent with past research suggesting the existence of a common habitus that appealed to the dominant student group within each campus, which comprised local students in this case (Berger, 2000). Local students seem more susceptible to social expectations, meaning that their active participation in hall activities can be predicted if their friends are active members too. Coupled with the findings related to the impact of a residence hall among non-local students, the current result resonates with Astin's student involvement theory (1984), which posits that positive outcomes are resulted from peer group involvement. The limited social gains reported by non-local students in the present study demonstrate their inactive involvement in social areas. It appears that they do not relate to peers throughout their hall experience, whether it is in cultivating friendships as a result of staying in a residence hall or joining residence hall activities due to the influence of peers.

In terms of the impact of hall experience on first-year and non-first-year students, both reported similar benefits in academic and social development. Although the non-significant differences reported contradict previous findings that students in their first year at a university generally benefited more from hall education than non-first-year (Tinto \& Goodsell, 1993; Yorke \& Longden, 2008), the current findings reflect a good university's hall system design. This means that the hall activities were well-rounded to suit the needs of both first-year and non-first-year students, and, consequently, residents across all years benefited from the hall activities to a similar extent. The only aspect with some differences was personal development. Results showed that non-first-years acquired significantly more leadership skills than first-years. This contradicts a previous study suggesting that the same leadership experience could have a decreasing impact when first-year students became senior year students (Foubert \& Grainger, 2006). While the study offers some insight, it is important to keep in mind that Foubert and Grainger's (2006) research focused on student's participation in clubs and organizations at university, it is possible that different nature of the university experience may affect student's developmental outcomes differently.

Generally, students in their first year at this university were found to be more significantly motivated to join hall activities than non-first-year students. This parallels past research indicating that first-years were eager to become involved in university life, joining hall activities can thus be a means to reach this goal (Arboleda et al., 2003; Beekhoven, 2002; Farris, 2010). Consequently, it is not surprising that first-years indicated more personal interest and a greater desire to achieve a well-rounded university experience. In contrast, non-first-years might become involved in other activities, which can explain their lack of active participation in hall activities compared to first-years (Arboleda et al., 2003).

There are certain limitations inherent in this research study. Since the present study was a quantitative study, including qualitative data such as students' perceptions of hall education and ways to improve their hall experience can be useful in developing a well-rounded understanding of the impact of hall experience on students. The potential meditating roles of students' involvement in residence halls, such as a students' leadership role and participation in hall activities, can also be investigated in future research. While students' reasons for participating in hall activities can be useful in inferring the extent of their hall participation, there may still be discrepancies in terms of their actual commitment in joining these activities. Additionally, investigating students' involvement in various hall activities can contribute to a better understanding of the potential hall activities that can most affect academic, social and personal development outcomes.

Another limitation is the generalizability of the research. As this research only included undergraduate students, it is uncertain whether the same findings would be observed among postgraduate students living in residence halls. Likewise, findings obtained from the study merely represent the residential hall experiences of students from a single public university in Hong Kong. Replication of the study in other institutional type is imperative to ensure that the present findings are not exclusive to the environmental and nationality factors of the institution in this study. 


\section{Implications for Practice}

After reviewing findings of this study, some recommendations for practice can be proposed. In response to the different hall experience for students of different genders, further stimulation of social and personal development outcomes for male residents is suggested. For instance, hall administrations can review current residential hall activities to implement more programs that can appeal to male residents (e.g. video game tournaments, darts competition, or football night). Likewise, as females tended to be more worried about their re-admission in the residence hall, further room for improvement in the design of hall activities is needed to create more appealing activities, so that female residents do not only choose to join hall activities with the goal of reducing negative consequences, but also consider intrinsic motivations by recognizing activities as rewarding and fulfilling to their university life. For instance, adding more popular hall activities of female choices such as organizing volunteering work together, peer support in study assignment, among other activities sought after by females in this residence hall.

On the other hand, to ensure that local and non-local students benefit from hall experience equally, further refinements in hall activities may be required. For example, to motivate further academic pursuit among local students, hall administrations can consider organizing more academic exchange or seminars. Additionally, as the present findings suggest that the current hall system at this university is largely rewarding to local students, further effort to extend the positive outcomes towards non-local students in regards to social and personal development may be needed. Future research may thus attempt to identify specific ways to fulfill these needs (e.g. story sharing of their customs/tradition of ethnic minorities, dressing up night of different cultures).

Another implication concerns the residential hall experience of first-year and non-first-year students. Since results revealed less leadership skills gained among first-years, more hall activities pertaining to leadership development or further leadership opportunities for first-years can encourage greater personal development. In a previous study, it was postulated that residents may prefer other activities as they approach graduation (Arboleda et al., 2003). For instance, non-first-years may be more concerned with career development. This complements the current finding that reported more motivations for participating in hall activities among first-year students. In such way, more relevant activities, such as career sharing or job shadowing may be more applicable to non-first-year students.

Despite the limitations put forward, the study provides useful information in identifying groups who may be more likely to benefit from hall education and those who may not. Findings can be useful to university student affairs and hall administrators in reducing the negative effects and expanding the positive effects of hall education. Results are also significant to the establishment of future policies of residence halls in further enhancing student learning outcomes, benefiting students of different genders, nationalities and year of study. It would also help students to reflect whether their hall life lives up to their expectations. For future students, an understanding of hall experience may also be useful when deciding whether to live in a residence hall or in other form of university accommodations.

In summary, a residence hall is not merely a place for accommodation but is also a significant part of the university experience in contributing to students' personal development. The present study examined the impact of living in residence halls and reasons for joining hall activities among students of different demographics. These include gender, nationality and year of study. Regarding gender differences, females were better developed in terms of social and personal development aspects than males as a result of staying in a residence hall. The same was observed among local students: not only did they report more social and personal development; they were also more socially motivated to participate in hall activities than non-local students. Likewise, while first-year and non-first-year students experienced similar outcomes from their hall education, the former were generally more motivated to participate in hall activities than the latter. The findings provide some insights into how students from different backgrounds experience hall education differently, which can be informative for hall administrators who wish to improve hall experience for students. Since hall education plays a critical role in student learning and development, future research should investigate the topic by replicating the research study and further delving into students' hall experience for a more comprehensive understanding of the topic. 


\section{References}

Arboleda, A., Wang, Y., Shelley, M. C., \& Whalen, D. F. (2003). Predictors of residence hall involvement. Journal of College Student Development, 44(4), 517-531.

Astin, A. W. (1984). Student involvement: A developmental theory for higher education. Journal of College Student Personnel, 25(4), 297-308.

Astin, A. W. (1993). What matters in college: Four critical years revisited. San Francisco, CA: Jossey-Bass. Beekhoven, S. (2002). A fair chance of succeeding: Study careers in Dutch higher education (Vol. 657). Amsterdam, The Netherlands: Rozenberg Publishers.

Berger, J. B. (2000). Optimizing capital, social reproduction, and undergraduate persistence. A sociological perspective. In J. M. Braxton (Ed.), Reworking the student departure puzzle (pp. 95-124). Nashville, TN: Vanderbilt University Press.

Bray, N. J. (2006). How college affects students: A third decade of research. The Journal of General Education, 55(2), 160-163.

Curley, P. (2003). Residence halls: Making campus a home. American School \& University, 75(12), 146149

Dusselier, L., Dunn, B., Wang, Y., Shelly, M., \& Whalden, D. (2005). Personal, health, academic, and environmental predictors of stress for residence hall students. Journal of American College Health, 54(1), 15-24. . PubMed.

Engstrom, C. M., \& Tinto, V. (2009). Pathways to student success: The impact of learning communities on the success of academically under-prepared college students: Final report prepared for the William and Flora Hewlett Foundation. Syracuse, NY: Higher Education, School of Education, Syracuse University.

Farris, A. K. (2010). The freshmen adjustment process: Commuter life versus residence life (Doctoral dissertation).

Flowers, L. A. (2004). Effects of living on campus on African American students' educational gains in college. NASPA Journal, 41(2), 277-293.

Foubert, J. D., \& Grainger, L. U. (2006). Effects of involvement in clubs and organizations on the psychosocial development of first-year and senior college students. NASPA Journal, 43(1), 166-182.

Franklin, D. S. (2013). Out-of-class learning and accountability in higher education. Procedia-Social and Behavioral Sciences, 90, 107-113

Gravetter, G. J., \& Wallnau, L. B. (2009). Statistics for the behavioral sciences. Belmont, CA: Wadsworth. Hall Education Development Project. (2012). About hall education. Retrieved from http://www.hedo.hku.hk/public/prevdoc/Abstract about HED Project.pdf

Helland, P. A., Stallings, H. J., \& Braxton, J. M. (2002). The fulfillment of expectations for college and student departure decisions. Journal of College Student Retention: Research, Theory \& Practice, 3(4), 381-396.

Holdsworth, C. (2006). 'Don't you think you're missing out, living at home? 'Student experiences and residential transitions. The Sociological Review, 54(3), 495-519.

Hornsey, M. J. (2008). Social identity theory and self-categorization theory: A historical review. Social and Personality Psychology Compass, 2(1), 204-222.

Huhn, C. (2006). The" housing effect" on first year outcomes (pp. 608). Madison, Wl: University of Wisconsin-Madison, Academic Planning and Analysis. 
Kashima, E. S., \& Loh, E. (2006). International students' acculturation: Effects of international, conational, and local ties and need for closure. International Journal of Intercultural Relations, 30(4), 471-485

Kuh, G. D., \& Hu, S. (2002). Being (Dis) engaged in educationally purposeful activities: The influences of student and institutional characteristics. Research in Higher Education, 43(5), 555-575.

Li, Y., Sheely, M. C., \& Whalen, D. F. (2005). Contributors to residence hall student retention: Why do students choose to leave or stay. Journal of College and University Student Housing, 33(2), 28-36.

Long, L. (2014). Does it matter where college students live? Differences in satisfaction and outcomes as a function of students' living arrangement and gender. The Journal of College and University Student Housing, 40(2), 66-85.

López Turley, R. N., \& Wodtke, G. (2010). College residence and academic performance: Who benefits from living on campus? Urban Education, 45(4), 506-532.

McCluskey-Titus, P., \& Oliver, R. (2001). The relationship between community development and academic achievement of undergraduate students in residence halls. College Student Affairs Journal, 20(2), 12. Newbrough, J. R. (1992). Community psychology in the postmodern world. Journal of Community Psychology, 20(1), 10-25.

Pike, G. R., Schroeder, C. S., \& Berry, T. R. (1997). Enhancing the educational impact of residence halls: The relationship between residential learning communities and first-year college experiences and persistence. Journal of College Student Development, 38, 609-621.

Roland, C. B., \& Enochs, W. K. (2006). Social adjustment to college freshmen: The importance of gender and living environment. College Student Journal, 40(1), 63-72.

Sherry, C., Bhat, R., Beaver, B., \& Ling, A. (2004, July). Students as customers: The expectations and perceptions of local and international students. Paper presented at HERDSA 2004 conference, Sarawak, Malaysia.

Tam, M. (2002). Measuring the effect of higher education on university students. Quality Assurance in Education, 10(4), 223-228.

Thomas, L. (2002). Student retention in higher education: The role of institutional habitus. Journal of Education Policy, 17(4), 423-442.

Ting, S. R., Chan, R., \& Lee, E. (2016). Involving students in residence halls in Hong Kong. Journal of College Student Development, 57(3), 300-315.

Tinto, V. (1986). Theories of student departure revisited. In J. Smart (Ed.), Higher education: Handbook of theory and research (Vol. 2, pp. 359-384). New York, NY: Agathon Press.

Tinto, V. (1993). Leaving college: Rethinking the causes and cures of student attrition. Chicago, IL: University of Chicago Press.

Tinto, V., \& Goodsell, A. (1993). A longitudinal study of freshman interest groups at the University of Washington. San Francisco, CA: Jossey-Bass.

Trepte, S., \& Loy, L. S. (2017). Social identity theory and self-categorization theory. In P. Rössler, C.A. Hoffner \& L. van Zoonen (Eds.), The International Encyclopedia of Media Effects (pp. 1832-1845). Malden, MA: John Wiley \& Sons.

The University of Hong Kong. (n.d.). Fees and scholarships. Retrieved May 23, 2018, from http://www.aal.hku.hk/admissions/international/admissions-information?page=en/fees-and$\underline{\text { scholarships }}$

Volet, S. E., \& Ang, G. (2012). Culturally mixed groups on international campuses: An opportunity for intercultural learning. Higher Education Research \& Development, 31(1), 21-37 
Wawrzynski, M. R., \& Jessup-Anger, J. E. (2010). From expectations to experiences: Using a structural typology to understand first-year student outcomes in academically based living-learning communities. Journal of College Student Development, 51(2), 201-217

Yang, M., \& Chau, A. W. L. (2011). Social involvement and development as a response to the campus student culture. Asia Pacific Education Review, 12, 393-402.

Yorke, M., \& Longden, B. (2008). The first-year experience of higher education in the UK. Final Report. York, UK: The Higher Education Academy.

Zepke, N., \& Leach, L. (2005). Integration and adaptation. Active Learning in Higher Education, 6(1), 4659 .

\section{Tables}

Table 1 Demographic Information of Participants

\begin{tabular}{lll}
\hline \multirow{4}{*}{ Gender } & & $(n=1234)$ \\
& Male & 561 \\
Nationality background & Enknown & 673 \\
& Local & 811 \\
& Non-local & 378 \\
Year of study & Unknown & 32 \\
& First-year & 480 \\
& Non-first-year & 740
\end{tabular}

Table 2 The Academic Impact of Hall Experience on Students from Different Groups

\begin{tabular}{|c|c|c|c|c|c|c|c|c|c|c|c|c|}
\hline $\begin{array}{l}\text { As a result of my hall } \\
\text { experience, }\end{array}$ & Male & & Fen & & $\begin{array}{l}\text { Loca } \\
\text { I }\end{array}$ & & Non & ocal & Firs & year & $\begin{array}{l}\text { Non } \\
\text { yea }\end{array}$ & first- \\
\hline & $\mathrm{M}$ & SD & $M$ & SD & $\mathrm{M}$ & SD & $M$ & SD & $M$ & SD & $\mathrm{M}$ & SD \\
\hline $\begin{array}{l}\text { Academic } \\
\text { development }\end{array}$ & & & & & & & & & & & & \\
\hline $\begin{array}{l}\text { I have a stronger } \\
\text { drive for excellence in } \\
\text { my } \\
\text { academic/professiona } \\
\text { I studies }\end{array}$ & $\begin{array}{l}3.5 \\
7\end{array}$ & $\begin{array}{l}0.9 \\
9\end{array}$ & $\begin{array}{l}3.5 \\
8\end{array}$ & $\begin{array}{l}0.9 \\
6\end{array}$ & 3.49 & $\begin{array}{l}0.9 \\
6\end{array}$ & $\begin{array}{l}3.7 \\
2\end{array}$ & $\begin{array}{l}1.0 \\
0\end{array}$ & $\begin{array}{l}3.6 \\
0\end{array}$ & $\begin{array}{l}0.9 \\
9\end{array}$ & $\begin{array}{l}3.5 \\
0\end{array}$ & $\begin{array}{l}0.9 \\
7\end{array}$ \\
\hline $\begin{array}{l}\text { My enthusiasm for } \\
\text { learning has been } \\
\text { further stimulated }\end{array}$ & $\begin{array}{l}3.4 \\
4\end{array}$ & $\begin{array}{l}0.9 \\
5\end{array}$ & $\begin{array}{l}3.4 \\
1\end{array}$ & $\begin{array}{l}0.9 \\
1\end{array}$ & 3.35 & $\begin{array}{l}0.9 \\
2\end{array}$ & $\begin{array}{l}3.5 \\
4\end{array}$ & $\begin{array}{l}0.9 \\
5\end{array}$ & $\begin{array}{l}3.4 \\
1\end{array}$ & $\begin{array}{l}0.9 \\
5\end{array}$ & $\begin{array}{l}3.3 \\
7\end{array}$ & $\begin{array}{l}0.9 \\
1\end{array}$ \\
\hline $\begin{array}{l}\text { I have achieved more } \\
\text { of my personal goals }\end{array}$ & $\begin{array}{l}3.3 \\
4\end{array}$ & $\begin{array}{l}0.9 \\
7\end{array}$ & $\begin{array}{l}3.3 \\
0\end{array}$ & $\begin{array}{l}0.9 \\
1\end{array}$ & 3.28 & $\begin{array}{l}0.9 \\
2\end{array}$ & $\begin{array}{l}3.3 \\
7\end{array}$ & $\begin{array}{l}0.9 \\
6\end{array}$ & $\begin{array}{l}3.3 \\
0\end{array}$ & $\begin{array}{l}0.9 \\
4\end{array}$ & $\begin{array}{l}3.2 \\
8\end{array}$ & $\begin{array}{l}0.9 \\
4\end{array}$ \\
\hline $\begin{array}{l}\text { I have acquired more } \\
\text { intellectual stimulation }\end{array}$ & $\begin{array}{l}3.5 \\
5\end{array}$ & $\begin{array}{l}0.9 \\
2\end{array}$ & $\begin{array}{l}3.4 \\
8\end{array}$ & $\begin{array}{l}0.8 \\
7\end{array}$ & 3.52 & $\begin{array}{l}0.8 \\
7\end{array}$ & $\begin{array}{l}3.4 \\
7\end{array}$ & $\begin{array}{l}0.9 \\
2\end{array}$ & $\begin{array}{l}3.4 \\
4\end{array}$ & $\begin{array}{l}0.8 \\
9\end{array}$ & $\begin{array}{l}3.5 \\
1\end{array}$ & $\begin{array}{l}0.8 \\
9\end{array}$ \\
\hline
\end{tabular}

Table 3 The Social Impact of Hall Experience on Students from Different Groups 


\begin{tabular}{|c|c|c|c|c|c|c|c|c|c|c|c|c|}
\hline $\begin{array}{l}\text { As a result of } \\
\text { my hall } \\
\text { experience, }\end{array}$ & Male & & Female & & Local & & Non-lo & & First-y & & $\begin{array}{l}\text { Non-fir } \\
\text { year }\end{array}$ & \\
\hline $\begin{array}{l}\text { Social } \\
\text { development }\end{array}$ & Mean & SD & Mean & SD & Mean & SD & Mean & SD & Mean & SD & Mean & SD \\
\hline $\begin{array}{l}\text { I am more } \\
\text { aware of the } \\
\text { thoughts and } \\
\text { feelings of } \\
\text { other people }\end{array}$ & 3.91 & 0.75 & 4.03 & 0.71 & 4.05 & 0.69 & 3.83 & 0.79 & 3.98 & 0.74 & 3.97 & 0.74 \\
\hline $\begin{array}{l}\text { I am more able } \\
\text { to see things } \\
\text { from other } \\
\text { people's point } \\
\text { of view }\end{array}$ & 3.92 & 0.74 & 4.06 & 0.68 & 4.05 & 0.69 & 3.90 & 0.75 & 3.97 & 0.73 & 4.01 & 0.71 \\
\hline $\begin{array}{l}\text { I have } \\
\text { developed a } \\
\text { better } \\
\text { understanding } \\
\text { of people of } \\
\text { different } \\
\text { cultural and } \\
\text { ethnic } \\
\text { backgrounds }\end{array}$ & 3.78 & 0.75 & 3.91 & 0.75 & 3.82 & 0.75 & 3.90 & 0.77 & 3.81 & 0.80 & 3.87 & 0.74 \\
\hline $\begin{array}{l}\text { I am more } \\
\text { aware of my } \\
\text { role as a } \\
\text { responsible } \\
\text { global citizen }\end{array}$ & 3.65 & 0.84 & 3.75 & 0.83 & 3.66 & 0.84 & 3.77 & 0.83 & 3.67 & 0.89 & 3.70 & 0.83 \\
\hline $\begin{array}{l}\text { I am more able } \\
\text { to see things } \\
\text { from a global } \\
\text { perspective }\end{array}$ & 3.60 & 0.86 & 3.65 & 0.83 & 3.53 & 0.85 & 3.70 & 0.82 & 3.58 & 0.88 & 3.63 & 0.84 \\
\hline $\begin{array}{l}\text { My skills in } \\
\text { social } \\
\text { communication } \\
\text { have improved }\end{array}$ & 3.90 & 0.74 & 4.01 & 0.71 & 4.02 & 0.69 & 3.85 & 0.78 & 3.92 & 0.74 & 3.98 & 0.72 \\
\hline $\begin{array}{l}\text { I am more able } \\
\text { to } \\
\text { communicate } \\
\text { my ideas with } \\
\text { people }\end{array}$ & 3.89 & 0.75 & 3.96 & 0.73 & 3.97 & 0.71 & 3.84 & 0.80 & 3.87 & 0.75 & 3.95 & 0.74 \\
\hline $\begin{array}{l}\text { I have learned } \\
\text { more about } \\
\text { how to } \\
\text { collaborate } \\
\text { with other } \\
\text { people in } \\
\text { completing } \\
\text { tasks }\end{array}$ & 3.85 & 0.76 & 3.95 & 0.73 & 3.99 & 0.71 & 3.75 & 0.82 & 3.86 & 0.75 & 3.92 & 0.76 \\
\hline $\begin{array}{l}\text { I have learned } \\
\text { more about } \\
\text { how to } \\
\text { negotiate with }\end{array}$ & 3.81 & 0.78 & 3.92 & 0.73 & 3.94 & 0.72 & 3.75 & 0.81 & 3.82 & 0.75 & 3.89 & 0.78 \\
\hline
\end{tabular}




\begin{tabular}{|c|c|c|c|c|c|c|c|c|c|c|c|c|}
\hline $\begin{array}{l}\text { As a result of } \\
\text { my hall } \\
\text { experience, }\end{array}$ & \multicolumn{2}{|l|}{ Male } & \multicolumn{2}{|c|}{ Female } & \multicolumn{2}{|l|}{ Local } & \multicolumn{2}{|c|}{ Non-local } & \multicolumn{2}{|c|}{ First-year } & \multicolumn{2}{|c|}{$\begin{array}{l}\text { Non-first- } \\
\text { year }\end{array}$} \\
\hline $\begin{array}{l}\text { Social } \\
\text { development }\end{array}$ & Mean & SD & Mean & SD & Mean & SD & Mean & SD & Mean & SD & Mean & SD \\
\hline $\begin{array}{l}\text { others in } \\
\text { coming to a } \\
\text { decision }\end{array}$ & & & & & & & & & & & & \\
\hline $\begin{array}{l}\text { I am more } \\
\text { aware of } \\
\text { issues like } \\
\text { human } \\
\text { equality, } \\
\text { fairness, and } \\
\text { justice }\end{array}$ & 3.63 & 0.82 & 3.73 & 0.83 & 3.67 & 0.83 & 3.69 & 0.83 & 3.64 & 0.85 & 3.68 & 0.82 \\
\hline $\begin{array}{l}\text { I have a } \\
\text { stronger sense } \\
\text { of belonging to } \\
\text { a community in } \\
\text { the university }\end{array}$ & 3.82 & 0.82 & 3.89 & 0.82 & 3.91 & 0.79 & 3.77 & 0.88 & 3.85 & 0.84 & 3.86 & 0.82 \\
\hline $\begin{array}{l}\text { I have a } \\
\text { stronger sense } \\
\text { of identity as a } \\
\text { member of the } \\
\text { university }\end{array}$ & 3.82 & 0.84 & 3.93 & 0.80 & 3.92 & 0.79 & 3.83 & 0.88 & 3.88 & 0.81 & 3.87 & 0.84 \\
\hline $\begin{array}{l}\text { As a result of } \\
\text { my hall } \\
\text { experience, }\end{array}$ & Male & & Female & & Local & & Non-lo & & First-ye & & $\begin{array}{l}\text { Non-fir: } \\
\text { year }\end{array}$ & \\
\hline $\begin{array}{l}\text { Personal } \\
\text { development }\end{array}$ & Mean & SD & Mean & SD & Mean & SD & Mean & SD & Mean & SD & Mean & SD \\
\hline $\begin{array}{l}\text { My analytical } \\
\text { skills have } \\
\text { been } \\
\text { sharpened }\end{array}$ & 3.66 & 0.83 & 3.63 & 0.76 & 3.72 & 0.75 & 3.49 & 0.86 & 3.59 & 0.79 & 3.65 & 0.80 \\
\hline $\begin{array}{l}\text { I am more able } \\
\text { to look at } \\
\text { things from } \\
\text { different } \\
\text { perspectives }\end{array}$ & 3.85 & 0.74 & 3.96 & 0.67 & 3.95 & 0.66 & 3.83 & 0.79 & 3.87 & 0.70 & 3.93 & 0.72 \\
\hline $\begin{array}{l}\text { I have further } \\
\text { developed } \\
\text { skills that will } \\
\text { enable me to } \\
\text { engage in life- } \\
\text { long learning }\end{array}$ & 3.77 & 0.77 & 3.87 & 0.71 & 3.86 & 0.72 & 3.73 & 0.78 & 3.79 & 0.72 & 3.82 & 0.76 \\
\hline $\begin{array}{l}\text { I feel more } \\
\text { confident about } \\
\text { tackling } \\
\text { unfamiliar } \\
\text { problems }\end{array}$ & 3.78 & 0.77 & 3.86 & 0.73 & 3.87 & 0.73 & 3.74 & 0.80 & 3.78 & 0.76 & 3.85 & 0.76 \\
\hline
\end{tabular}




\begin{tabular}{|c|c|c|c|c|c|c|c|c|c|c|c|c|}
\hline $\begin{array}{l}\text { As a result of } \\
\text { my hall } \\
\text { experience, }\end{array}$ & Male & & Femal & & Local & & Non-lo & & First-y & & $\begin{array}{l}\text { Non-fir } \\
\text { year }\end{array}$ & \\
\hline $\begin{array}{l}\text { Personal } \\
\text { development }\end{array}$ & Mean & SD & Mean & SD & Mean & SD & Mean & SD & Mean & SD & Mean & SD \\
\hline $\begin{array}{l}\text { I have learned } \\
\text { more about } \\
\text { how to identify } \\
\text { a problem and } \\
\text { tackle it }\end{array}$ & 3.76 & 0.77 & 3.84 & 0.70 & 3.85 & 0.71 & 3.68 & 0.77 & 3.79 & 0.73 & 3.79 & 0.75 \\
\hline $\begin{array}{l}\text { I feel more } \\
\text { confident when } \\
\text { I am put in a } \\
\text { new situation }\end{array}$ & 3.83 & 0.79 & 3.88 & 0.77 & 3.86 & 0.78 & 3.84 & 0.79 & 3.81 & 0.81 & 3.87 & 0.77 \\
\hline $\begin{array}{l}\text { I have become } \\
\text { more aware of } \\
\text { my personal } \\
\text { strengths and } \\
\text { weaknesses }\end{array}$ & 3.92 & 0.79 & 3.98 & 0.71 & 4.01 & 0.73 & 3.84 & 0.78 & 3.90 & 0.73 & 3.98 & 0.76 \\
\hline $\begin{array}{l}\text { I maintain } \\
\text { higher } \\
\text { standards of } \\
\text { personal } \\
\text { integrity }\end{array}$ & 3.77 & 0.78 & 3.84 & 0.73 & 3.83 & 0.74 & 3.75 & 0.80 & 3.78 & 0.75 & 3.80 & 0.76 \\
\hline $\begin{array}{l}\text { I have learned } \\
\text { more about } \\
\text { how to pursue } \\
\text { ethical } \\
\text { practices in } \\
\text { social, } \\
\text { academic and } \\
\text { professional } \\
\text { settings }\end{array}$ & 3.66 & 0.81 & 3.71 & 0.79 & 3.69 & 0.80 & 3.69 & 0.81 & 3.67 & 0.79 & 3.65 & 0.82 \\
\hline $\begin{array}{l}\text { I have acquired } \\
\text { more } \\
\text { leadership } \\
\text { skills }\end{array}$ & 3.63 & 0.86 & 3.72 & 0.79 & 3.75 & 0.82 & 3.50 & 0.83 & 3.55 & 0.84 & 3.73 & 0.83 \\
\hline $\begin{array}{l}\text { I am more } \\
\text { confident in } \\
\text { taking up a } \\
\text { leadership role }\end{array}$ & 3.62 & 0.89 & 3.71 & 0.80 & 3.74 & 0.83 & 3.50 & 0.84 & 3.55 & 0.84 & 3.72 & 0.86 \\
\hline $\begin{array}{l}\text { My } \\
\text { commitment to } \\
\text { making the } \\
\text { world a better } \\
\text { place for all to } \\
\text { live in has } \\
\text { been } \\
\text { enhanced }\end{array}$ & 3.56 & 0.85 & 3.64 & 0.79 & 3.59 & 0.82 & 3.59 & 0.83 & 3.59 & 0.81 & 3.57 & 0.84 \\
\hline $\begin{array}{l}\text { I have } \\
\text { cultivated a } \\
\text { more } \\
\text { inquisitive mind }\end{array}$ & 3.64 & 0.80 & 3.70 & 0.75 & 3.70 & 0.76 & 3.60 & 0.80 & 3.64 & 0.77 & 3.66 & 0.79 \\
\hline
\end{tabular}




\begin{tabular}{|c|c|c|c|c|c|c|c|c|c|c|c|c|}
\hline $\begin{array}{l}\text { As a result of } \\
\text { my hall } \\
\text { experience, }\end{array}$ & Male & & Female & & Local & & Non-lo & & First-ye & & $\begin{array}{l}\text { Non-fir } \\
\text { year }\end{array}$ & \\
\hline $\begin{array}{l}\text { Personal } \\
\text { development }\end{array}$ & Mean & SD & Mean & SD & Mean & SD & Mean & SD & Mean & SD & Mean & SD \\
\hline $\begin{array}{l}\text { I have } \\
\text { achieved more } \\
\text { of my personal } \\
\text { goals }\end{array}$ & 3.67 & 0.81 & 3.73 & 0.77 & 3.73 & 0.77 & 3.65 & 0.83 & 3.67 & 0.78 & 3.70 & 0.81 \\
\hline $\begin{array}{l}\text { My time } \\
\text { management } \\
\text { skills have } \\
\text { improved }\end{array}$ & 3.68 & 0.90 & 3.71 & 0.85 & 3.69 & 0.87 & 3.69 & 0.89 & 3.67 & 0.88 & 3.67 & 0.88 \\
\hline $\begin{array}{l}\text { I have adopted } \\
\text { a lifestyle that } \\
\text { is more } \\
\text { conducive to } \\
\text { my } \\
\text { psychological } \\
\text { wellness }\end{array}$ & 3.61 & 0.87 & 3.60 & 0.89 & 3.58 & 0.89 & 3.63 & 0.88 & 3.54 & 0.89 & 3.60 & 0.90 \\
\hline $\begin{array}{l}\text { I have adopted } \\
\text { a lifestyle that } \\
\text { is more } \\
\text { conducive to } \\
\text { my physical } \\
\text { wellness }\end{array}$ & 3.56 & 0.97 & 3.51 & 1.01 & 3.50 & 1.04 & 3.57 & 0.93 & 3.47 & 1.10 & 3.52 & 1.00 \\
\hline
\end{tabular}

Note. 1-Strongly disagree, 2-Disagree, 3-Neutral, 4-Agree, 5-Strongly agree $\left({ }^{*} p<0.05,{ }^{* *} 0<0.01\right)$.

Table 5 Reasons for Joining Hall Activities According to Students from Different Groups

\begin{tabular}{lllllllllllll}
\hline Reasons & Male & \multicolumn{1}{l}{ Female } & Local & & Non-local & First-year & \multicolumn{2}{l}{$\begin{array}{l}\text { Non- first- } \\
\text { year }\end{array}$} \\
& & & & & & & & & & & & \\
& M & M & SD & M & SD & M & SD & M & SD & M & SD \\
Self-improvement & 3.8 & 0.9 & 3.7 & 0.8 & 3.8 & 0.9 & 3.7 & 0.8 & 3.7 & 1.0 & 3.7 & 0.9 \\
& 1 & 1 & 6 & 1 & 1 & 4 & 2 & 9 & 5 & 4 & 1 & 1 \\
Personal interest & 4.1 & 0.8 & 4.0 & 0.7 & 4.1 & 0.7 & 4.1 & 0.8 & 4.1 & 0.8 & 4.0 & 0.7 \\
& 7 & 0 & 8 & 2 & 5 & 9 & 0 & 0 & 9 & 9 & 8 & 9 \\
Commitment/contribution & 3.5 & 1.0 & 3.4 & 0.8 & 3.5 & 0.9 & 3.5 & 0.9 & 3.6 & 1.0 & 3.5 & 0.9 \\
n to hall & 6 & 0 & 9 & 8 & 9 & 7 & 4 & 6 & 6 & 7 & 6 & 2 \\
Meeting/making friends & 3.9 & 0.8 & 3.9 & 0.7 & 4.0 & 0.8 & 3.9 & 0.8 & 4.0 & 0.9 & 3.9 & 0.8 \\
& 7 & 7 & 5 & 7 & 7 & 0 & 2 & 7 & 2 & 5 & 9 & 2 \\
Achieving a more well- & 3.9 & 0.9 & 3.9 & 0.7 & 4.0 & 0.8 & 3.8 & 0.8 & 3.9 & 0.9 & 3.9 & 0.7 \\
rounded university life & 1 & 0 & 6 & 9 & 4 & 2 & 7 & 6 & 1 & 4 & 6 & 9 \\
Increasing the chance & 3.1 & 1.2 & 2.8 & 1.1 & 3.2 & 1.2 & 3.1 & 1.2 & 3.6 & 1.1 & 3.2 & 1.1 \\
of re-admission & 6 & 4 & 8 & 2 & 4 & 0 & 7 & 1 & 8 & 6 & 4 & 6 \\
Being considered for & 2.5 & 1.1 & 2.4 & 1.0 & 2.5 & 1.0 & 2.4 & 1.1 & 2.5 & 1.2 & 2.4 & 1.0 \\
awards & 3 & 9 & 5 & 9 & 6 & 7 & 2 & 7 & 3 & 0 & 2 & 7 \\
Peer encouragement & 3.2 & 1.0 & 3.3 & 0.9 & 3.3 & 1.0 & 3.2 & 0.9 & 3.1 & 1.1 & 3.2 & 0.9 \\
& 6 & 3 & 4 & 1 & 3 & 1 & 3 & 8 & 7 & 1 & 8 & 6 \\
Peer pressure & 2.5 & 1.0 & 2.6 & 0.9 & 2.5 & 1.0 & 2.5 & 1.0 & 2.3 & 1.1 & 2.4 & 1.0 \\
& 4 & 7 & 0 & 9 & 0 & 3 & 1 & 9 & 7 & 4 & 7 & 6 \\
\hline
\end{tabular}




\begin{tabular}{|c|c|c|c|c|c|c|c|c|c|c|c|c|}
\hline \multirow[t]{2}{*}{ Reasons } & \multicolumn{2}{|c|}{ Male } & \multicolumn{2}{|c|}{ Female } & \multicolumn{2}{|c|}{ Local } & \multicolumn{2}{|c|}{ Non-local } & \multicolumn{2}{|c|}{ First-year } & \multicolumn{2}{|c|}{$\begin{array}{l}\text { Non- first } \\
\text { year }\end{array}$} \\
\hline & $\mathrm{M}$ & SD & $\mathrm{M}$ & SD & M & SD & M & SD & M & SD & M & SD \\
\hline $\begin{array}{l}\text { Experiencing unity and } \\
\text { group achievement }\end{array}$ & $\begin{array}{l}3.5 \\
4\end{array}$ & $\begin{array}{l}1.0 \\
1\end{array}$ & $\begin{array}{l}3.5 \\
4\end{array}$ & $\begin{array}{l}0.8 \\
5\end{array}$ & $\begin{array}{l}3.5 \\
9\end{array}$ & $\begin{array}{l}0.9 \\
2\end{array}$ & $\begin{array}{l}3.5 \\
1\end{array}$ & $\begin{array}{l}1.0 \\
1\end{array}$ & $\begin{array}{l}3.5 \\
5\end{array}$ & $\begin{array}{l}1.1 \\
4\end{array}$ & $\begin{array}{l}3.5 \\
5\end{array}$ & $\begin{array}{l}0.9 \\
4\end{array}$ \\
\hline Avoiding penalty & $\begin{array}{l}2.2 \\
3\end{array}$ & $\begin{array}{l}1.2 \\
4\end{array}$ & $\begin{array}{l}2.1 \\
9\end{array}$ & $\begin{array}{l}1.1 \\
5\end{array}$ & $\begin{array}{l}2.3 \\
9\end{array}$ & $\begin{array}{l}1.2 \\
3\end{array}$ & $\begin{array}{l}2.1 \\
4\end{array}$ & $\begin{array}{l}1.1 \\
6\end{array}$ & $\begin{array}{l}2.3 \\
0\end{array}$ & $\begin{array}{l}1.2 \\
6\end{array}$ & $\begin{array}{l}2.2 \\
4\end{array}$ & $\begin{array}{l}1.1 \\
5\end{array}$ \\
\hline
\end{tabular}

